\title{
ON THE TWO-POINT OSTROWSKI INEQUALITY
}

\author{
JOSIP PEČARIĆ AND ŠIME UNGAR
}

Abstract. We prove the $L_{p}$-version of an inequality similar to the two-point Ostrowski inequality of Matić and Pečarić [4].

Mathematics subject classification (2010): 26D15, 26D10.

Keywords and phrases: Integral inequality, two-point Ostrowski, $p$-norm.

\section{REFERENCES}

[1] A. Aglić Aljinović, J. PeČArić, I. Perić, Estimations of the difference of two weighted integral means via weighted Montgomery identity, Mathematical Inequalities \& Applications, 73 (2004), 315336.

[2] N. S. BARNETT, S. S. DRAGOMIR, Issues of estimation in the monitoring of constant flow continuous streams, RGMIA, Research report collection, 23 (1999), 275-282.

[3] S. S. Dragomir, An inequality of Ostrowski type via Pompeiu's mean value theorem, Journal of Inequalities in Pure and Applied Mathematics, Vol. 6, 383 (2005), 1-9.

[4] M. Matić, J. PeČARIĆ, Two-point Ostrowski inequality, Mathematical Inequalities \& Applications, 4 2 (2001), 215-221.

[5] A. Ostrowski, Über die Absolutabweichung einer differentienbaren Funktionen von ihren Integralmittelwert, Comment. Math. Hel., 10 (1938), 226-227.

[6] J. PEČARIĆ, I. PERIĆ, A. VUKELIĆ, Estimations of the difference of two integral means via Euler-type identities, Mathematical Inequalities \& Applications, 73 (2004), 365-378.

[7] J. PEČARIĆ, Š. UnGAR, On an inequality of Ostrowski type, Journal of Inequalities in Pure and Applied Mathematics, Vol. 7, 4, 151 (2006), 1-5.

[8] D. Pompeiu, Sur une proposition analogue au théorème des accroissements finis, Mathematica (Cluj, Romania), 22 (1946), 143-146. 